\title{
Prediction of Sediment Yield from Southern Plains Grasslands with the Modified Uni- versal Soil Loss Equation
}

\author{
S.J. SMITH, J.R. WILLIAMS, R.G. MENZEL, AND G.A. COLEMAN
}

\section{Abstract}

Amounts of sediment per runoff event from grassland watersheds in the Texas Blackland Prairie, Southern High Plains, Central Rolling Red Prairies, and Central Rolling Red Plains land resource areas of Oklahoma and Texas were predicted using the modified Universal Soil Loss Equation (MUSLE). In this equation,

$$
Y=11.8\left(Q q_{p}\right)^{0.56} \mathrm{KCPSL}
$$

where $Y$ = sediment yield in metric tons, $Q=$ runoff volume in $\mathrm{m}^{3}, q_{p}$ $=$ peak runoff rate in $\mathrm{m}^{3} / \mathrm{sec}, K=$ soil erodibility factor, $\mathrm{C}=$ crop management factor, $\mathbf{P}=$ erosion control-practice factor, and $\mathrm{SL}=$ slope length, gradient factor. Periods of study were 3 to 5 years and included treatments involving grazing density, fertilization, cultivation, and burning. Over the range of watersheds, average measured sediment yield varied from less than 10 to more than $\mathbf{8 0 0}$ $\mathrm{kg} / \mathrm{ha} /$ event. In most cases, the predicted values compared favorably to the field measured values.

Accurate prediction of sediment yield from watersheds is important from land use, management, and environmental standpoints. To aid in this prediction Williams (1975) developed the Modified Universal Soil Loss Equation (MUSLE), by replacing the rainfall energy factor of the USLE (Wischmeier and Smith 1960) with a runoff energy factor. The energy factor in MUSLE is a function of the product of the runoff volume and the peak runoff rate for an individual storm. As noted by Williams (1981), MUSLE has certain advantages over USLE, especially in simulating sediment yield from a watershed. The advantages include (1) application to individual storms, (2) elimination of the need for sediment delivery ratios because the runoff factor reflects energy used in sediment transport as well as in sediment detachment, and (3) greater accuracy because runoff generally accounts for more sediment yield variation than does rainfall. In fact, the Sedimentation Task Committee (1970) of the Hydraulics Division, American Society of Civil Engineers, has stated that runoff is the best single indicator of sediment yield. To date, initial results with MUSLE have been encouraging (Williams 1981, Cooley and Williams 1983, Smith et al. 1983) but additional testing is necessary to fully document the equation's utility in specific land resource areas and under different land management conditions. The present study involves application of the equation to grassland watersheds in the Texas Blackland Prairie (BP), Southern High Plains (HP), Central Rolling Red Prairies (RP), and Central Rolling Red Plains (RRP) major land resource areas of Oklahoma and Texas (Soil Conservation Service 1981).

\section{Procedures and Watersheds}

Equation Development

In the original development of MUSLE (Williams 1975), mea-

Authors are soil scientist, hydraulic engineer, soil scientist, and hydraulic engineer, respectively. Address of Smith, Menzel, and Coleman is Water Quality and Watershed Research Laboratory, P.O. Box 1430, Durant, Okla. 74702. Address of Williams is Grassland, Soil, and Water Research Lab., P.O. Box 748, Temple, Tex. 76503.

Technical assistance by ARS personnel at El Reno and Woodward, Okla., and Bushland and Temple, Tex., is gratefully acknowledged.

Manuscript accepted October 20, 1983. sured data provided runoff rates and volumes to form the runoff energy factor. This factor was then substituted for the rainfall energy factor in the USLE and an optimization technique (DeCoursey and Synder 1969) was employed to determine the prediction equation. This equation, MUSLE, may be stated as:

$$
\mathrm{Y}=11.8\left(\mathrm{Qq}_{\mathrm{p}}\right)^{0.56} \mathrm{KCPSL}
$$

Where $Y=$ sediment yield in metric tons,

$$
\begin{aligned}
Q & =\text { runoff volume in } \mathrm{m}^{3}, \\
\mathrm{q}_{\mathbf{p}} & =\text { peak runoff rate in } \mathrm{m}^{3} / \mathrm{sec}, \\
\mathbf{K} & =\text { soil erodibility factor, } \\
\mathbf{C} & =\text { crop management factor, } \\
\mathbf{P} & =\text { erosion control-practice factor, and } \\
\mathbf{S L} & =\text { slope length, gradient factor. }
\end{aligned}
$$

Except for substituting the runoff energy factor, $11.8\left(Q q_{p}\right)^{0.56}$ for the rainfall energy factor in USLE, the remainder of the equation is identical to USLE.

\section{Watersheds}

General details about the watersheds are included in the left part of Table 1. More specific information has been provided in earlier publications (Sharpley et al. 1982, Smith et al. 1983). Suffice it to note here that the watersheds provided good representation of the land resource areas, encompassing a range of soils, slopes, and grasses. Size varied from 0.04 to 122 ha and periods of study were 3 to 5 years. Watershed slopes ranged from 1 to almost $9 \%$. During the period of study annual rainfall ranged from 43 to $95 \mathrm{~cm}$, and mean annual runoff ranged from 1.2 to $24 \mathrm{~cm}$. Treatments included annual grazing, deferred grazing, fertilization, spring burning, and cultivation. Grazing intensities varied from none (HP) to double stocking (RP, FR 1). Prior to the study, the BP and HP watersheds were in tame/virgin grassland or cropland, and all others were in good condition, virgin grassland. After 2 years half of the RP and RRP watersheds were placed in continuous wheat. The BP and HP continuous cropland watersheds, which were in sorghum-cottonoats and wheat-sorghum-fallow rotations, respectively, have been included mainly for comparative purposes.

\section{Field Measurement and Sampling}

Except for the small 0.04-ha HP grassland watersheds, runoff was measured using precalibrated flumes or weirs equipped with FW-1 stage recorders. Sediment discharge was collected from suspended sediment concentrations taken automatically for the duration of each hydrograph. After comparison with the runoff hydrograph, samples for a specific watershed were composited in proportion to total flow to provide a single representative sample of liquid and sediment. In the case of the HP grassland watersheds, a "splitting device" was employed that collected about $1 / 10$ of the respective runoff. Sediment concentration was determined gravimetrically after removal of liquid.

\section{Testing Procedure}

For each watershed, the MUSLE predictions were determined using runoff energy factors which involved measured runoff volumes and peak flow rates from individual events. The other 
Table 1. Sediment yield characteristics of Southern Plains watersheds.

\begin{tabular}{|c|c|c|c|c|c|c|c|c|c|c|c|}
\hline \multirow{2}{*}{$\begin{array}{l}\text { Major land } \\
\text { Res. area! }\end{array}$} & \multirow[b]{2}{*}{ Watershed } & \multirow{2}{*}{$\begin{array}{c}\text { Size } \\
\text { ha }\end{array}$} & \multirow{2}{*}{$\begin{array}{c}\text { Average } \\
\text { slope } \\
\%\end{array}$} & \multirow{2}{*}{$\begin{array}{l}\text { Period of } \\
\text { record }\end{array}$} & \multirow{2}{*}{$\begin{array}{l}\text { Number of } \\
\text { events }\end{array}$} & \multicolumn{2}{|c|}{ Mean yield/event } & \multicolumn{2}{|c|}{ Std. Dev. } & \multirow[b]{2}{*}{$\mathbf{R}^{2}$} & \multirow{2}{*}{$\begin{array}{l}\text { Regression } \\
\text { slope }\end{array}$} \\
\hline & & & & & & Meas. & Pred. & Meas. & Pred. & & \\
\hline & & & & & & - (20سـ & Gr & nds & - & & \\
\hline $\mathbf{B P}$ & $\begin{array}{c}\text { SW11 } \\
\text { W10 } \\
\text { Y14 }\end{array}$ & $\begin{array}{l}1.08 \\
7.97 \\
2.27\end{array}$ & $\begin{array}{l}0.98 \\
2.10 \\
1.38\end{array}$ & $\begin{array}{l}77-80 \\
76-80 \\
77-80\end{array}$ & $\begin{array}{l}20 \\
18 \\
28\end{array}$ & $\begin{array}{r}278 \\
23 \\
124\end{array}$ & $\begin{array}{r}287 \\
23 \\
128\end{array}$ & $\begin{array}{r}349 \\
21 \\
280\end{array}$ & $\begin{array}{r}376 \\
23 \\
264\end{array}$ & $\begin{array}{l}0.91 \\
0.88 \\
0.77\end{array}$ & $\begin{array}{l}0.89 \\
0.84 \\
0.93\end{array}$ \\
\hline HP & $\begin{array}{l}\text { NG } \\
\text { SG }\end{array}$ & $\begin{array}{l}0.04 \\
0.04\end{array}$ & $\begin{array}{l}1.00 \\
1.00\end{array}$ & $\begin{array}{l}78-80 \\
78-80\end{array}$ & $\begin{array}{l}4 \\
4\end{array}$ & $\begin{array}{r}8 \\
14\end{array}$ & $\begin{array}{r}9 \\
13\end{array}$ & $\begin{array}{l}10 \\
22\end{array}$ & $\begin{array}{l}11 \\
16\end{array}$ & $\begin{array}{l}0.97 \\
0.92\end{array}$ & $\begin{array}{l}0.84 \\
1.30\end{array}$ \\
\hline $\mathbf{R P}$ & $\begin{array}{l}\text { FR1 } \\
\text { FR2 } \\
\text { FR3 } \\
\text { FR4 }\end{array}$ & $\begin{array}{l}1.62 \\
1.62 \\
1.62 \\
1.62\end{array}$ & $\begin{array}{l}2.58 \\
2.88 \\
3.18 \\
3.64\end{array}$ & $\begin{array}{l}77-80 \\
77-80 \\
77-80 \\
77-80\end{array}$ & $\begin{array}{l}20 \\
17 \\
19 \\
21\end{array}$ & $\begin{array}{r}7 \\
8 \\
8 \\
15\end{array}$ & $\begin{array}{r}7 \\
8 \\
9 \\
15\end{array}$ & $\begin{array}{l}13 \\
15 \\
20 \\
59\end{array}$ & $\begin{array}{l}15 \\
16 \\
19 \\
56\end{array}$ & $\begin{array}{l}0.89 \\
0.96 \\
0.96 \\
0.99\end{array}$ & $\begin{array}{l}0.84 \\
0.95 \\
1.08 \\
1.05\end{array}$ \\
\hline RRP & $\begin{array}{l}\text { WW1 } \\
\text { WW2 }\end{array}$ & $\begin{array}{l}4.80 \\
5.56\end{array}$ & $\begin{array}{l}7.00 \\
8.20\end{array}$ & $\begin{array}{l}77-80 \\
77-80\end{array}$ & $\begin{array}{l}34 \\
54\end{array}$ & $\begin{array}{r}10 \\
111\end{array}$ & $\begin{array}{r}11 \\
111\end{array}$ & $\begin{array}{c}25 \\
299\end{array}$ & $\begin{array}{r}23 \\
255\end{array}$ & $\begin{array}{l}0.94 \\
0.88\end{array}$ & $\begin{array}{l}1.06 \\
1.10\end{array}$ \\
\hline $\mathbf{R P}$ & $\begin{array}{l}\text { FR5 } \\
\text { FR6 } \\
\text { FR7 } \\
\text { FR8 }\end{array}$ & $\begin{array}{l}1.62 \\
1.62 \\
1.62 \\
1.62\end{array}$ & $\begin{array}{l}3.48 \\
2.88 \\
2.88 \\
2.73\end{array}$ & $\begin{array}{l}77-80 \\
77-80 \\
77-80 \\
77-80\end{array}$ & $\begin{array}{l}26 \\
23 \\
28 \\
29\end{array}$ & $\begin{array}{l}\text { Gre } \\
50 \\
46 \\
25 \\
26\end{array}$ & $\begin{array}{c}\text { nds to } \\
63 \\
47 \\
37 \\
18\end{array}$ & $\begin{array}{c}\text { Land } \\
157 \\
133 \\
64 \\
71\end{array}$ & $\begin{array}{r}198 \\
148 \\
95 \\
36\end{array}$ & $\begin{array}{l}1.00 \\
0.94 \\
0.99 \\
0.69\end{array}$ & $\begin{array}{l}0.80 \\
0.87 \\
0.67 \\
1.66\end{array}$ \\
\hline RRP & $\begin{array}{l}\text { WW3 } \\
\text { WW4 }\end{array}$ & $\begin{array}{l}2.71 \\
2.91\end{array}$ & $\begin{array}{l}8.60 \\
7.40\end{array}$ & $\begin{array}{l}77-80 \\
77-80\end{array}$ & $\begin{array}{l}29 \\
40\end{array}$ & $\begin{array}{l}51 \\
38\end{array}$ & $\begin{array}{l}51 \\
37\end{array}$ & $\begin{array}{r}168 \\
99\end{array}$ & $\begin{array}{r}164 \\
85\end{array}$ & $\begin{array}{l}1.00 \\
0.88\end{array}$ & $\begin{array}{l}1.02 \\
1.09\end{array}$ \\
\hline BP & $\begin{array}{r}\mathrm{Y} \\
\mathrm{Y} 2\end{array}$ & $\begin{array}{r}122 \\
53\end{array}$ & $\begin{array}{l}2.57 \\
2.86\end{array}$ & $\begin{array}{l}76-80 \\
76-80\end{array}$ & $\begin{array}{l}50 \\
34\end{array}$ & $\begin{array}{c}\text { Mixed } \\
74 \\
148\end{array}$ & $\begin{array}{c}\text { ds (Gra } \\
58^{*} \\
174\end{array}$ & $\begin{array}{c}\text { ads and } \\
118 \\
191\end{array}$ & $\begin{array}{r}\text { lands) } \\
83 \\
231\end{array}$ & $\begin{array}{l}0.90 \\
0.83\end{array}$ & $\begin{array}{l}1.36 \\
0.75\end{array}$ \\
\hline BP & $\begin{array}{r}\text { Y6 } \\
\text { Y8 } \\
\text { Y10 }\end{array}$ & $\begin{array}{l}6.6 \\
8.4 \\
7.5\end{array}$ & $\begin{array}{l}3.21 \\
2.24 \\
1.88\end{array}$ & $\begin{array}{l}76-80 \\
76-80 \\
76-80\end{array}$ & $\begin{array}{l}24 \\
18 \\
23\end{array}$ & $\begin{array}{l}542 \\
343 \\
812\end{array}$ & $\begin{array}{l}\text { Cropla } \\
534 \\
343 \\
632\end{array}$ & $\begin{array}{r}481 \\
550 \\
1125\end{array}$ & $\begin{array}{l}364 \\
487 \\
783\end{array}$ & $\begin{array}{l}0.60 \\
0.98 \\
0.84\end{array}$ & $\begin{array}{l}1.02 \\
1.12 \\
1.32\end{array}$ \\
\hline HP & $\begin{array}{l}\text { G10 } \\
\text { G11 } \\
\text { G12 }\end{array}$ & $\begin{array}{l}3.3 \\
2.6 \\
2.1\end{array}$ & $\begin{array}{l}1.80 \\
2.00 \\
2.20\end{array}$ & $\begin{array}{l}78-80 \\
78-80 \\
78-80\end{array}$ & $\begin{array}{l}16 \\
19 \\
15\end{array}$ & $\begin{array}{l}396 \\
364 \\
428\end{array}$ & $\begin{array}{l}386 \\
286 \\
531\end{array}$ & $\begin{array}{l}859 \\
798 \\
827\end{array}$ & $\begin{array}{r}782 \\
640 \\
1060\end{array}$ & $\begin{array}{l}0.99 \\
0.98 \\
0.94\end{array}$ & $\begin{array}{l}1.09 \\
1.23 \\
0.76\end{array}$ \\
\hline
\end{tabular}

"Statistically different at $5 \%$ level from measured value using the t-test, paired data.

'BP, Texas Blackland Prairie; HP, Southern High Plains; RP, Central Rolling Red Prairie; R RP, Central Rolling Red Plains.

factors, K,C,P, and SL. in Eq. [1], were obtained from Agricultural Handbook 537 (Wischmeier and Smith 1978). In the case of the grasslands, $P$ was unity and $K, C$, and SL ranged from 0.28 to 0.37 , 0.002 to 0.400 , and 0.14 to 1.05 , respectively. Statistical methods were conducted using standard procedures as outlined in Snedecor (1956). In the case of the linear regression analysis, a slope greater than unity indicates sediment yield is overpredicted, whereas a slope less than unity indicates sediment yield is underpredicted.

\section{Results and Discussion}

A comparison of the MUSLE predicted and the actual measured amounts of sediment yield on an event basis for the individual watersheds is detailed in the right part of Table 1. Obviously, a wide range of results within and among watersheds was obtained, with mean sediment yields per event ranging from essentially none to as much as $812 \mathrm{~kg} /$ ha on the $\mathrm{Y} 10$ cropland watershed. Prediction of mean sediment yields and respective standard deviations was quite satisfactory, particularly in the case of the continuous grassland watersheds. In general, $R^{2}$ values for both grasslands and croplands were 0.8 or higher and the regression slopes were close to unity. Moreover, using the paired $t$-test as a basis for difference, only the $\mathrm{Y}$ mixed land-use watershed (containing both grassland and cropland subwatersheds) exhibited a statistical difference ( $p=$ 0.05 ) between the predicted and measured sediment yields. Even here, the predicted and measured means, 58 and $74 \mathrm{~kg} / \mathrm{ha} /$ event, respectively, were fairly close. Therefore, when viewed in light of the wide range of land uses and conditions involved, the general utility of MUSLE is considered good.

While knowledge of sediment yield on an event basis is necessary from a water quality/ environmental modeling standpoint, annual

Table 2. Measured and predicted runoff and sediment yields for Texas Blackland Prairie grasslands'.

\begin{tabular}{|c|c|c|c|c|c|c|c|c|c|}
\hline \multirow[b]{3}{*}{ Watershed } & \multirow{3}{*}{$\begin{array}{l}\text { Period of } \\
\text { record }\end{array}$} & \multicolumn{4}{|c|}{ Annual runoff } & \multicolumn{4}{|c|}{ Annual sediment yield } \\
\hline & & \multicolumn{2}{|c|}{ Mean } & \multicolumn{2}{|c|}{ Std. Dev. } & \multicolumn{2}{|c|}{ Mean } & \multicolumn{2}{|c|}{ Std. Dev. } \\
\hline & & Meas. & Pred & Meas. & Pred. & Meas. & Pred. & Meas. & Pred. \\
\hline & & & $-\mathrm{cm}-$ & & & & $-\mathrm{kg} / \mathrm{ha}$ & & \\
\hline SW-11 & $77-80$ & 15 & 14 & 14 & 12 & 1330 & 1110 & 930 & 820 \\
\hline W10 & $76-80$ & 25 & 26 & 13 & 13 & 82 & 82 & 98 & 44 \\
\hline Y14 & $77-80$ & 20 & 24 & 14 & 16 & 820 & 1040 & 1110 & 1810 \\
\hline
\end{tabular}




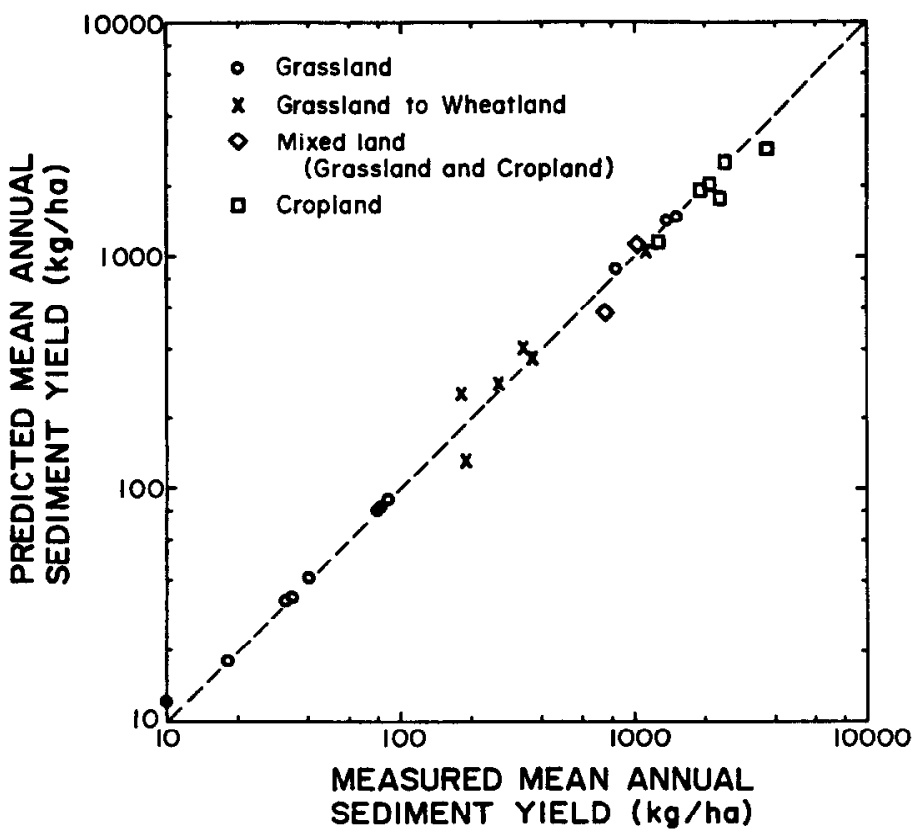

Fig. 1. A comparison of the MUSLEpredicted and actual measured mean annual sediment yields for the watersheds.

sediment yields are often desired from a land management/conservation planning standpoint. Figure 1 is a plot of the mean annual MUSLE predicted and the actual measured sediment yields for the various watersheds. Mean annual measured sediment yields ranged from $10 \mathrm{~kg} / \mathrm{ha}$ for the NG, HP grassland watershed to $3,700 \mathrm{~kg} / \mathrm{ha}$ for the Y10, BP cropland watershed. In general, MUSLE performed satisfactorily for all the watershed types, with the good fit between mean annual predicted and measured sediment yields for the grasslands particularly evident. In view of the fact that the Soil Conservation Service tolerable annual soil loss limits for the RRP grasslands and other watersheds are 5,550 and $11,100 \mathrm{~kg} / \mathrm{ha}$, respectively', none of the watersheds posed serious erosion problems during the study periods ( 3 to 5 years). This encouraging piece of information should be tempered, however, by the statement that the grassland watersheds were all in good condition prior to initiation of the study, and the cropland watersheds were farmed according to recommended practice.

The test results in the present study were made using measured runoff volumes and peak runoff rates. In general practice, however, such information is not available. In these cases MUSLE may be linked with hydrologic simulation models (Williams and Berndt 1977) to provide estimates of $\left(\mathrm{Qq}_{\mathrm{p}}\right)$ in $\mathrm{Eq}$. (1). As

Tolerable annual soil losses. File copy received 1981, SCS, Stillwater, Okla. an example, MUSLE was combined with several other hydrologic components to form the EPIC (Erosion-Productivity Impact Calculator) model (Williams et al. 1982). Preliminary results (Table 2) using an estimated $\left(\mathrm{Qq}_{\mathrm{p}}\right)$ term from the EPIC model are encouraging.

Overall, the results of this study leave little doubt that MUSLE can be a useful tool for predicting sediment yields from grassland watersheds in major land resource areas of the Southern Plains. Moreover, results with the mixed land-use watersheds (containing both grassland and cropland subwatersheds) support the view (Williams 1981) that MUSLE has utility on a multiple as well as individual watershed basis. Consequently, MUSLE may have application to larger, basin-scale, land areas.

\section{Literature Cited}

Cooley, K.R., and J.R. Williams. 1983. Applicability of the USLE and MUSLE to Hawaiian Agricultural Lands. In: Proc. Internat. Conf. on Soil Erosion and Conservation, Honolulu, Hawaii.

DeCoursey, D.G., and W.M.Snyder. 1969. Computer-oriented method of optimizing hydrologic model parameters. J. Hydrology 9:34-56.

Sedimentation Task Committee. 1970. Sedimentation engineering, Chap. IV. Sediment sources and sediment yields. Proc. Amer. Soc. Civil Engr. 96 (HY6): 1283-1329.

Sharpley, A.N., S.J. Smith, and R.G. Menzel. 1982. Prediction of phosphorus losses in runoff from Southern Plains watersheds. J. Environ. Qual. 11:247-251.

Smith, S.J., R.G. Menzel, E.D. Rhoades, J.R. Williams, and H.V. Eck. 1983. Nutrient and sediment discharge from Southern Plains grasslands. J. Range Manage. (Accepted for publication).

Snedecor, G.W. 1956. Statistical Methods, 5th Ed. lowa State Univ. Press, Ames.

Soil Conservation Service. 1981. Land resource regions and major land resource areas of the United States. USDA, Agr. Handbook 296, Washington, D.C.

Williams, J.R. 1975. Sediment-yield prediction with Universal Equation using runoff energy factor. p. 244-252. In: Present and Prospective Technology for Predicting Sediment Yield and Sources. U.S. Dep. Agr. ARS-S-40.

Williams, J.R. 1981. Testing the modified Universal Soil Loss Equation. p. 157-164. In: Fstimating Erosion and Sediment Yield on Rangelands. USDA. ARM-W-26.

Williams, J.R., and H.D. Berndt. 1977. Sediment yield prediction based on watershed hydrology. Trans. Amer. Soc. Agr. Eng. 20:1100-1104.

Williams, J.R., P.T. Dyke, and C.A. Jones. 1982. EPIC-A model for assessing the effects of erosion on soil productivity. In: Proc. Third Int. Conf. on State-of-the-Art in Ecological Modeling, Fort Collins, CO.

Wischmeier, W.H. and D.D.Smith. 1960. A universal soil-loss equation to guide conservation farm planning. 7th Int. Cong. Soil Sci. Trans. 1:418-425.

Wischmeier, W.H. and D.D. Smith. 1978. Predicting rainfall erosion losses. U.S. Dep. Agr., Sci. Ed. Admin., Agr. Handbook 537. Washington, D.C. 